\title{
Molecular Weight Estimation of Esterase Isoenzymes in Closely Related Drosophila Species (Diptera: Drosophilidae) in Non-Denaturing Polyacrylamide Gel Electrophoresis
}

\author{
Rogério Pincela Mateus ${ }^{1^{*}}$, Hamilton Cabral $^{2}$, Gustavo Orlando Bonilla-Rodriguez ${ }^{3}$ and \\ Carlos Roberto Ceron ${ }^{3}$ \\ ${ }^{1}$ Laboratório de Genética e Evolução; Departamento de Ciências Biológicas; Universidade Estadual do Centro- \\ Oeste; 85.040-080; Guarapuava - PR - Brasil. ${ }^{2}$ Departamento de Ciências Farmacêuticas; Universidade de São \\ Paulo; Ribeirão Preto - SP - Brasil. ${ }^{3}$ Departamento de Química e Ciências Ambientais; Universidade Estadual \\ Paulista; São José do Rio Preto - SP - Brasil
}

\begin{abstract}
A method that allows the measure of molecular weight of two well-known and closely related esterases from Drosophila mojavensis and its sibling species, D. arizonae, is here described, using native polyacrylamide gel electrophoresis at several concentrations, applying Fergunson's principles. These enzymes, namely EST-4 and EST5 , presented molecular weight values between 81 and $91 \mathrm{kDa}$. In spite of their distinct expression pattern through the insect's life cycle, they showed properties of isoenzymes codified by distinct structural genes, supporting the hypothesis of a rather recent gene duplication event that generated both in $\mathrm{D}$. mojavensis and $\mathrm{D}$. arizonae, as well as in other species of repleta group. The method is simple and adequate to be applied to preliminary molecular weight determination of other enzymes without any previous purification procedure.
\end{abstract}

Key words: Esterases, Isoenzymes, molecular weight determination, Drosophila mojavensis, Drosophila arizonae, PAGE

\section{INTRODUCTION}

High resolution of polyacrylamide gel electrophoresis constitutes a valuable technique for separation and characterization of macromolecules, including protein and nucleic acids. The use of this technique in separation of native proteins is established considering both the molecule size and charge, and it also can be used to determine some of their physical-chemical properties. If electrophoresis is performed under the identical conditions, in different gel concentrations, distances traveled by protein molecule will vary. In this case, a plot of $\log$ of protein relative mobility $\left(\mathrm{R}_{\mathrm{m}}\right)$ versus gel concentration results in a straight line with negative slope (Ferguson's plot). The slope of such plot is related to molecular weight of protein (Ferguson, 1964; Hedrick and Smith, 1968).

In this work, the molecular weight (MW) of related esterases was estimated applying the principles described above. Such procedure has the advantage of allowing a preliminary MW determination without any previous protein purification method, such as Bio-Gel (Sierecka, 1998), Phenyl Sepharose (Marco and Felix, 2007) or Chitosan gel column (Tang and Qian, 2007). Two esterases, EST-4 and EST-5, found in the

\footnotetext{
* Author for correspondence: rmateus@unicentro.br
} 
sibling species pair Drosophila mojavensis and $D$. arizonae, well characterized by Zouros and Johnson (1976), were selected. These enzymes exhibit preferential activity over $\beta$-naphthyl acetate and present distinct expression patterns. EST-4 shows specific late third instar larvae activity and it is found in the carcass. EST-5 presents constant activity through insect's life cycle and it is detected in haemolymph and fat body. Several studies (Zouros et al., 1982; Zouros and Van Delden, 1982) supported that both esterases were coded by two distinct loci in the Drosophila repleta species group and probably had a common origin through a gene duplication event. Therefore, the aim of this work was to estimate the molecular weight of these enzymes using a simple technique and discuss results in the light of these closely related esterases evolution.

\section{MATERIAL AND METHODS}

Drosophila mojavensis and D. arizonae were originally obtained from the Genetics Foundation, University of Texas (Austin, USA). Homozygous strains for EST-4 and EST-5 for both species were achieved after endogamic crosses. The strains were maintained at $20^{\circ} \mathrm{C}+/-1^{\circ} \mathrm{C}$ on banana-agar medium.

Electrophoreses were performed according to Laemmli (1970) discontinuous buffer system, but omitting SDS. Standard molecular weight proteins, individual samples of late third instar larvae and five days old females from both species were stacked in 3\% slab gels, built up in $0.125 \mathrm{M}$ Tris$\mathrm{HCl}$ buffer ( $\mathrm{pH}$ 6.9), followed by separation in resolving gels at concentrations varying from 6 to $12 \%(\mathrm{C}=2.6 \%)$, prepared in $0.37 \mathrm{M}$ Tris- $\mathrm{HCl}(\mathrm{pH}$ 8.8). All the electrophoreses were conducted at $200 \mathrm{~V}$ for a period of three hours and 30 minutes.

Gels were firstly stained for esterase activity according to Lapenta et al. (1995), using $\beta$ naphthyl acetate as substrate, followed by total protein staining with Comassie Blue RR salt. Standard molecular weight proteins used were myoglobin $(\mathrm{MW}=17.8 \mathrm{kDa})$, soybean trypsin inhibitor $(24 \mathrm{kDa})$, carbonic anhydrase $(29 \mathrm{kDa})$, ovalbumin $(45 \mathrm{kDa})$, human serum albumin $(66$ $\mathrm{kDa})$ and phosphorylase-b (97.4 kDa).

Migrations for standard proteins and esterases were measured in each gel using a millimetric rule.
Relative migrations $\left(\mathrm{R}_{\mathrm{m}}\right)$ were obtained dividing protein migration by dye front (bromophenol blue) migration. Plots of $\log \mathrm{R}_{\mathrm{m}}$ versus gel concentration were constructed for all proteins. A linear regression for each protein was obtained fitting a curve to the data set using the equation $Y=\mathrm{A}+$ $\mathrm{B} X$, where $\mathrm{A}$ is the interception of the $Y$ axis and $\mathrm{B}$ is the slope (both given). All graphics were constructed using a Microcal Origin software, version 3.5 (Scientific and Technical Graphics in Windows - copyright c 1991 - 1994, Microcal Software Inc.).

\section{RESULTS}

$R_{m}$ protein values changed as negative exponential function of gel concentrations. Thus, plots of log $R_{m}$ versus gel concentration of standard proteins produced straight lines with negative slopes, as observed in Fig. 1A. These slope values are presented in Table 1, along with the respective standard protein MW. Using these data, it was possible to construct a plot of slopes values (multiplied by -1) versus standard proteins MW. The linear regression generated a straight line that fitted a curve using the equation already mentioned (Fig. 1B).

$\mathrm{R}_{\mathrm{m}}$ values for EST-4 and EST-5 from $D$. mojavensis and $D$. arizonae were determined in the same conditions as standard proteins. Fig. 2 (A and $B$ ) shows plots of $\log R_{m}$ versus gel concentration for these esterases in both species. It could be observed that EST-4 and EST-5 produced parallel straight lines with negative slopes, where EST-4 was always below EST-5.

Negative slope values and molecular weight estimatives for EST-4 and EST-5 in D. mojavensis and $D$. arizonae were obtained from data displayed in Fig. 2 (A and B) by interpoling calculated slope values for EST-4 and EST-5 of both species in the graph of Fig. 1B. Slopes and MW estimatives for these esterases are presented in Table 2. D. mojavensis showed the highest MW values for both the enzymes, $87.45 \mathrm{kDa}$ for EST-4 and $86.14 \mathrm{kDa}$ for EST-5. In D. arizonae, these values were $85.59 \mathrm{kDa}$ (EST-4) and $84.4 \mathrm{kDa}$ (EST-5). Taking in account standard deviations, these four enzymes presented MW values between 81 and $91 \mathrm{kDa}$. 


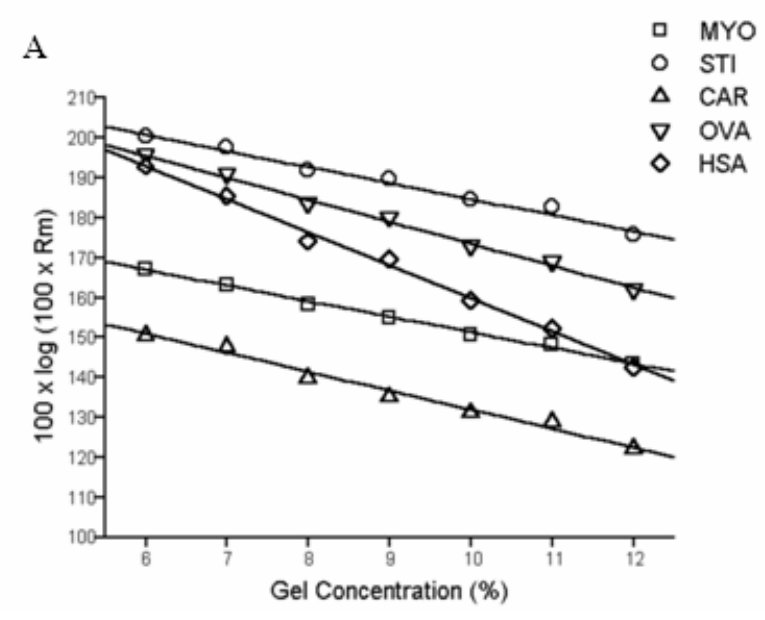

\section{$\mathbf{B}$}

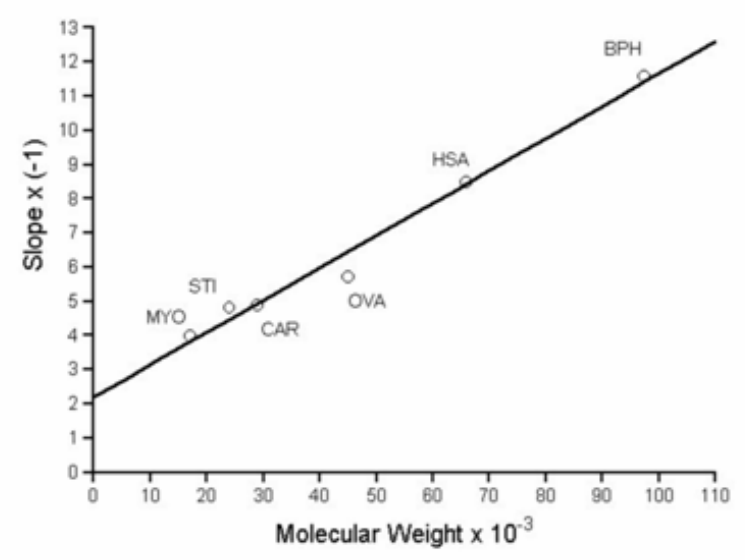

Figure 1 - Standard proteins submitted to electrophoresis at several polyacrylamide gel concentrations. (A) Log $\mathrm{R}_{\mathrm{m}}$-gel concentration relationship (Ferguson's plot). (B) Slope (-1)-molecular weight standard proteins relationship. MYO = myoglobin; STI = soybean trypsin inhibitor; $\mathrm{CAR}=$ carbonic anhydrase; OVA = ovalbumin; HSA = human serum albumin; $\mathrm{BPH}=$ phosphorylase $\mathrm{b}$. Slope values were calculated for each standard protein from data presented in figure 1A, and are shown in Table 1.

Table 1 - Standard proteins and their $\log \mathrm{R}_{\mathrm{m}}$-gel concentration relationships. The $\log \mathrm{R}_{\mathrm{m}}$ versus gel concentration produced straight lines with negative slopes for each standard protein, as shown in Figure 1-A.

\begin{tabular}{lcc}
\hline Standard Proteins & Molecular Weight (kDa) & slopes (+/- sd) \\
\hline Myoglobin & 17.8 & $-3.90944(+/-0.16402)$ \\
Soybean trypsin inhibitor & 24 & $-4.02255(+/-0.19507)$ \\
Carbonic anhydrase & 29 & $-4.75683(+/-0.25265)$ \\
Ovalbumin & 45 & $-5.49993(+/-0.15652)$ \\
Human serum albumin & 66 & $-8.25322(+/-0.23871)$ \\
Phosphorylase- $b$ & 97.4 & $-11.59043(+/-0.22478)$ \\
\hline
\end{tabular}



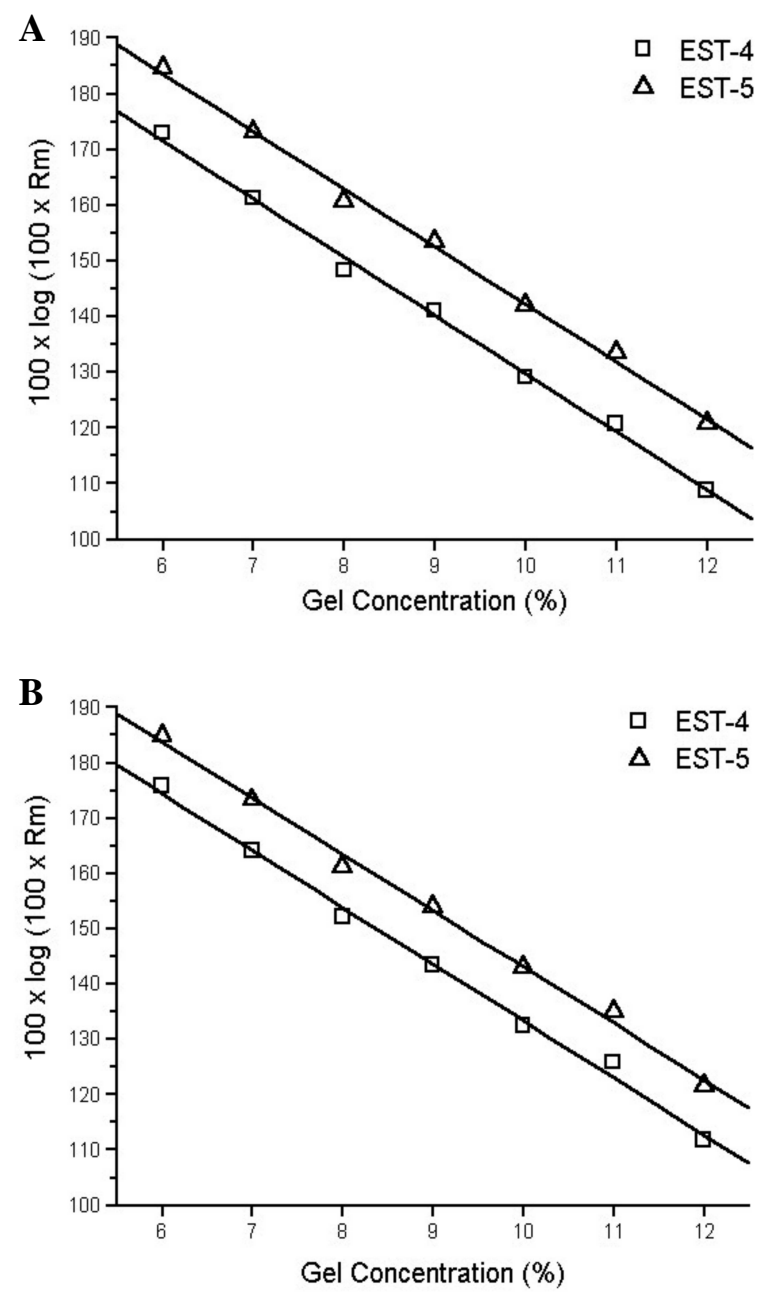

Figure 2 - $\log \mathrm{R}_{\mathrm{m}}$ - gel concentrations relationship (Ferguson's plot) for EST-4 and EST-5 isoenzymes. A - Drosophila mojavensis; B - Drosophila arizonae.

Table 2 - Log $\mathrm{R}_{\mathrm{m}}$-gel concentration relationships and molecular weight estimates of Drosophila mojavensis and D. arizonae EST-4 and EST-5 isoenzymes.

\begin{tabular}{lccc}
\hline Species & & Slope $(+/-$ sd) & Molecular Weight (+/- sd) \\
\hline Drosophila mojavensis & EST-4 & $-10.45339+/-0.27581$ & $87.450+/-2.918$ \\
& EST-5 & $-10.33036+/-0.27437$ & $86.148+/-2.903$ \\
\hline Drosophila arizonae & EST-4 & $-10.27775+/-0.32146$ & $85.591+/-3.401$ \\
& EST-5 & $-10.16554+/-0.30570$ & $84.404+/-3.234$ \\
\hline
\end{tabular}

\section{DISCUSSION}

Protein structures are not destroyed in electrophoresis accomplished under native conditions, allowing exploiting differences in their sizes, charges and shapes. If proteins are separated under identical conditions, but with different gel concentrations, the distance traveled by them will vary, according to their $\mathrm{R}_{\mathrm{m}}$. In this case, the intercepts at gel concentration (T) equal $0 \%$ are a measure of free mobility $(\mu 0)$ and slopes are related to protein molecular sizes. Four deductions can be made according to the plots of $\log R_{m}$ versus gel concentration. The first is when slopes are parallel. In this situation proteins have similar size but different mobility, as in the case of 
isoenzymes. The second one occurs when slopes are different, but lines do not cross. In this case, the protein corresponding to the upper line is smaller and has a higher net charge. The third deduction can be made when lines cross at $\mathrm{T}>$ $2 \%$. This means that larger protein has higher charge density and intercepts the $\mathrm{Y}$-axis at higher value. Finally several lines cross at a point where $\mathrm{T}<2 \%$, as shown in the case for the various polymers of one protein (Tietz, 1995). In this work, these concepts were exploited in the study of two well-known esterases, EST-4 and EST-5, found in $D$. mojavensis and its sibling $D$. arizonae. Graphic analysis for both the enzymes demonstrated that they presented MW values between 81 and $91 \mathrm{kDa}$ (Table 2). Previous studies have estimated a MW between 85 and $95 \mathrm{kDa}$ for EST-4 in D. mojavensis using gel filtration HPLC and Sephadex G-150 chromatrography (Pen et al., 1984). Our results also confirmed that EST-4 and EST-5 had very close hydrodynamic properties as observed by their relationships in native polyacrylamide gels (Figure $2-\mathrm{A}$ and $\mathrm{B}$ ) indicating that they shared properties of isoenzymes under this situation.

Previous genetic studies have suggested that the genes encoding EST-4 and EST-5 in $D$. mojavensis and $D$. arizonae, despite their expression pattern at different developmental periods and different tissue localization, are part of a tandem duplication as old as $D$. repleta group (Zouros et al., 1982). The same was postulated for EST-1 and EST-J in D. buzzatii (East et al., 1990), another member of $D$. repleta species group. These enzymes are classified as $\beta$-esterases, codified by the genes belonging to $\beta$-esterase cluster gene (Oakeshott et al., 1990; 1993). Although EST-4 and EST-5 were differently located in the insect's body and were expressed at different periods during the development, they indeed seemed to be products of the gene duplication, showing $82 \%$ identity in N-terminal amino acid sequences (Pen et al., 1986). EST-5 was probably the enzyme that maintained its original properties among species of $D$. repleta group and, on the other hand, after duplication, the pattern of expression of EST-4 was changed in the group ancestral as several species expressed this enzyme in the carcass of late third instar larvae. After speciation, biochemical differences arose between EST-4 enzymes of different species, as detected in this and other works. A comparison of
$\mathrm{N}$ - terminal sequences among several esterases demonstrated that EST-4 and EST-5 from $D$. mojavensis belonged to the homologous family of serine esterases, with EST-6 and EST-P from $D$. melanogaster being their closest relatives (Myers et al., 1988; Pen et al., 1990).

Several authors have recently discussed relevant aspects and mechanisms of evolution by gene duplication, including the role of selection in the process (Wagner, 2002; Zhang, 2003; Hurles, 2004). In Drosophila species, $\beta$-esterase gene cluster (Korochkin et al., 1987) is constituted by two (three in the case of D. pseudoobscura) closely linked genes, which have the same direction of transcription and similar exon/intron structure (Collet et al., 1990). It is believed that a gene duplication event gives rise to this gene cluster and it is relatively ancient since this arrangement is found in representative species encompassing $D$. virilis, $D$. repleta, $D$. melanogaster and D. obscura species groups (Yenikolopov et al., 1989; Brady et al., 1990; East et al., 1990; Oakeshott et al., 1990; 1993).

In $D$. pseudoobscura, $\beta$-esterase cluster gene is formed by three linked paralogous genes, Est-5C, Est-5B and Est-5A, located in X chromosome (Brady et al., 1990). Brady and Richmond (1992) proposed an evolutionary history of Est-5 gene duplication in D. pseudoobscura with reference to Est-6 and Est-P in D. melanogaster. (more recently Est-P gene was considered a pseudogene and renamed as $\Psi E s t-6$ by Balakirev and Ayala, 1996). This history was based on nucleotide sequence, patterns of gene expression and properties of corresponding enzymes. The authors also postulated that the first gene duplication event predated the divergence of $D$. pseudooscura and D. melanogaster and originated the Est- $5 A-E s t-P$ (YEst-6) lineage and Est-5B/C - Est 6 lineage. A second duplication in $D$. pseudoobscura lineage gave rise to Est-5B and Est-5C. Further studies provided evidences that gene conversion between loci contributed to polymorphism and to the homogenization of the Est-5 genes in this latter species (King, 1998). Both Est-5A gene of D. pseudoobsucra and $\Psi E s t-6$ of D. melanogaster are expressed under certain constraints only in late third instar larvae (Collet et al., 1990; Dumanic et al., 1997; Balakiev and Ayala, 2003 and 2004).

Results presented in this work showed that EST-4 and EST-5 in D. mojavensis and D. arizonae have properties of isoenzymes, in agreement to previous 
studies about gene duplication event that generated these $\beta$-esterases. Furthermore, the method is simple and adequate to be applied in molecular weight determination of other enzymes, mostly because it has the advantage of determining a protein molecular weight without any previous purification method.

\section{ACKNOWLEDGMENTS}

We wish to thank CNPq for funding Rogério P. Mateus (Master's degree fellowship). We also wish to thank CAPES, FINEP and FUNDUNESP for supporting this work, Eliani Nobuco Ikeguchi Ohira for technical support, Dr. Hermione Elly Melara Campos Bicudo for the Drosophila stocks, and Dr. Cláudia Maria Ceneviva Nigro for language revision.

\section{RESUMO}

Neste trabalho, um método que permite a estimativa do peso molecular de duas esterases conhecidas e intimamente relacionadas, encontradas em Drosophila mojavensis e sua espécie aparentada $D$. arizonae, é descrito. Este método é realizado utilizando a técnica de eletroforese em diferentes concentrações de gel e aplicando os princípios de Fergunson. As enzimas, denominadas EST-4 e EST-5, apresentaram pesos moleculares entre 81 e $91 \mathrm{kDa}$. Apesar de seus padrões diferenciados de expressão durante o ciclo de vida do inseto, elas demonstraram propriedades de enzimas codificadas por genes estruturais distintos, corroborando a hipótese de um evento de duplicação gênica recente que gerou ambas em $D$. mojavensis e $D$. arizonae, bem como em outras espécies do grupo repleta. O método proposto é simples e adequado para ser utilizado em estimativas preliminares de determinação de pesos moleculares de outras enzimas sem haver a necessidade de um procedimento prévio de purificação.

\section{REFERENCES}

Balakirev, E. S. and Ayala, F. J. (1996), Is esterase P encoded by a criptic pseudogene in Drosophila melanogaster? Genetics, 144, 1511-1518.

Balakirev, E. S. and Ayala, F. J. (2003), Pseudogens: are they "junk" or functional DNA? Ann. Rev. Genet., 37, 123-151.

Balakirev, E. S. and Ayala, F. J. (2004), The $\beta$-esterase gene clustr of Drosophila melanogaster: is $\Psi E s t-6$ a pseudogene, a functional gene or both? Genetica, 121, 165-179.

Brady, J. P.; Richmond, R. C. and Oakeshott, J. G. (1990), Cloning of the esterase-5 locus from Drosophila pseudoobscura and comparison with its homologue in D. melanogaster. Mol. Biol. Evol., 7, 525-546.

Brady, J. P. and Richmond, R. C. (1992), An evolutionary model for the duplication and divergence of esterase genes in Drosophila. J. Mol. Evol., 34, 506-521.

Collet, C.; Nielsen, K. M.; Russell, R. J.; Karl, M.; Oakeshott, J. G. and Richmond, R. C. (1990), Molecular analysis of duplicated esterase genes in Drosophila melanogaster. Mol. Biol. Evol., 7, 9-28.

Dumanic, M. M.; Oakeshott, J. G.; Russel, R. J. and Healy, M. J. (1997), Characterization Of the EstP protein in Drosophila melanogaster and its conservation in Drosophilids. Biochem. Genet., 35, 252-271.

East, P. D.; Graham, A. and Whitington, G. (1990), Molecular isolation and preliminary characterization of a duplicated esterase locus in Drosophila buzzatii. In-Ecological Genetics and Evolution, The Cactusyeast-Drosophila model system, ed. J. S. F. Baker, W. T. Starmer and R. J. McInture. Plenum Press, New York, pp. 389-406..

Ferguson, K. A. (1964), Starch-gel electrophoresis-application to the classification of pituitary proteins and polypeptides. Metabolism, 13, 985-1002.

Hedrick, J. L. and Smith, A. J. (1968), Size and charge isomer separation and estimation of molecular weights of proteins by disc gel electrophoresis. Arch. Biochem. Bioph., 126, 155-164.

Hurles, M. (2004), Gene duplication: The genomic trade in spare parts. PLoS Biol., 2, 0900-0904.

King, L. M. (1998), The role of gene conversion in determining sequence variation and divergence in the Est-5 gene family in Drosophila pseudoobscura. Genetics, 148, 305-315. 
Korochkin, L.; Ludwig, M. Z.; Poliakova, E. V. and Philinova, M. R. (1987), Some molecular genetic aspects of cellular differentiation in Drosophila. Sov. Sci. Rev. F. Physiol. Gen. Biol., 1, 411-466.

Laemmli, U. K. (1970), Cleavage of structural proteins during the assembly of the head of bacteriophage $\mathrm{T}_{4}$.

Nature, 227, 680-685.

Lapenta, A. S.; Bicudo, H. E. M. C.; Ceron, C. R. and Manzato, J. A. (1995), Esterase patterns of species in the Drosophila buzzatii cluster. Cytobios, 84, 13-29.

Marco, J. L. and Felix, C. R. (2007), Purification and characterization of a beta-Glucanase produced by Trichoderma harzianum showing biocontrol potential. Braz. Arch. Biol. Technol., 50, 21-29.

Myers, M.; Richmond, R. C. and Oakeshott, J. G. (1988), On the origins of esterases. Mol. Biol. Evol., 5, 113-119.

Oakeshott, J. G.; Healy, M. J. and Game, A. Y. (1990), Regulatory evolution of ß-carboxyl esterases in Drosophila. In-Ecological and evolutionary genetics of Drosophila, ed. J. F. S. Barker, T. W. Starmer and R. J. MacIntyre. Plenum Press, New York, pp. 359387.

Oakeshott, J. G.; van Papenrecht, E. A.; Boyce, T. M.; Healy, M. J. and Russel, R. J. (1993), Evolutionary genetics of Drosophila esterases. Genetica, 90, 239268.

Pen, J.; Rongen, H. A. H. and Beintema, J. J. (1984), Purification and properties of esterase-4 form Drosophila mojavensis. Biochem. Biophys, Acta, $\mathbf{7 8 9}$, 203-209.

Pen, J.; van Beeumen, J. and Beintema, J. J. (1986), Structural comparison of two esterases from Drosophila mojavensis isolated by immunoaffinity chromatography. Biochem. J., 238, 691-699.

Pen, J.; Bolks, G. J.; Hoeksema-Du Pui, M. L. L. and Beintema, J. J. (1990), Serine esterases: structural conservation during animal evolution and variability in enzymic properties in the genus Drosophila. Genetica, 81, 125-131.
Sierecka, J. K. (1998), Purification and partial characterization of a neutral protease from a virulent strain of Bacillus cereus. The Intl. J. Biochem. Cell Biol., 30, 579-595.

Tang, Z. X. and Qian, J. Q. (2007), Use of chitosan gel for the purification of protein. Braz. Arch. Biol. Technol., 50, 299-309.

Tietz, D. (1995), Benefits of advanced gel electrophoresis data analysis methods. Appl. Theor. Electrophor., 5, 107-111.

Wagner, A. (2002), Selection and gene duplication: a view from the genome. Genome Biol., 3, 1012.11012.3.

Yenikolopov, G. N.; Malevantschuk, O. A.; Peunova, N. I.; Sergeen, P. V. and Georgiev, G. P. (1989), Est locus of Drosophila virilis contains two related genes. Dokl. Acad. Nauk. URRS, 306, 1247-1249.

Zhang, J. (2003), Evolution by gene duplication: an update. Trends Ecol. Evol., 18, 292-298.

Zouros, E. and Johnson, W. (1976), Linkage disequilibrium between functionally related enzyme loci of Drosophila mojavensis. Can. J. Genet. Cytol., 18, 245-254.

Zouros, E. and van Delden, W. (1982), Substratepreference polymorphism at an esterase locus of Drosophila mojavensis. Genetics, 100, 307-314.

Zouros, E.; van Delden, W.; Odense, R. and van Dijk, H. (1982), An esterase duplication in Drosophila: differences in expression of duplicate loci within and among related species. Biochem. Genet., 20, 929-942.

Received: February 06, 2006; Revised: May 24, 2007; Accepted: September 02, 2008. 